\title{
THE ECONOMIC STRUCTURE AND PERFORMANCE OF THE CATCHMENT AREA OF THE HUNGARIAN REGIONAL CENTERS
}

\author{
Judit BERKES ${ }^{\mathrm{a}}$
}

a Széchenyi István University, Kautz Gyula Faculty of Business and Economics, H-9026 Győr, Egyetem tér 1., Hungary; e-mail: berkes.judit@sze.hu

Cite this article: Berkes, J. (2020). The economic resource of the catchment area of the Hungarian regional centers. Deturope. 12(3): 58-81.

\begin{abstract}
This study examines the economic structure and performance of urban catchment areas. The five largest Hungarian regional centers are a traditional part of the Hungarian city network, as they are the five most populous cities after Budapest. The approach of territorial research is increasingly focused on the fact that the city as a center should not be studied without its immediate surroundings (agglomeration, region, catchment area). This study also keeps this in mind. The data were processed for the period between 1992 and 2015, on the basis of which the change can also be examined. Development trajectories show very different tendencies; Györ operates the catchment area as a strong center, while the surroundings of Pécs became fragmented due to the weakness of the center. Miskolc is characterized by a stagnant area, where the operation of another sub-center is very intensive, thus improving economic performance. Szeged is a solid center, whose catchment area is stabilized by several substations. The area of Debrecen is divided, the center is not able to energize its area.
\end{abstract}

Keywords: economic structure, economic performance, economy of Hungarian catchment areas, regional centers

\section{INTRODUCTION}

Cities are important stakeholders of regional processes, as they have a number of functions that are responsible for the region's quantitative growth and quality improvement. On the other hand, special mention should be made of the settlements of the area surrounding the city and their characteristics. In this space, complex "movements" and relationships are created in which the effects of the participants' developmental processes on each other are expected to be well defined and have a significant impact on the quality of life of the population.

It is a well-known fact that the imbalance in the Hungarian urban network is constantly increasing as a result of the social and economic resources of Budapest (Beluszky, 2014; Kovács, 2017). Some attempts have been made in the past century to slow down or stop the process, e.g. the National Concept for Settlement Network Development of 1971 and its predecessor drawing on the main principles of French spatial planning (Egyed, 2016), but 
these were not very successful, although we believe that this process cannot and should not be slowed down. Budapest's international weight is steadily increasing (Rácz, 2019), although it is clearly not considered to be a metropolis of European significance (Hajdú et al. 2017), but its economic strength to attract foreign capital makes it the most suitable city for transnational corporations, thus the continuity of its growth is organic. However, this study focuses on the next level of the hierarchy, the role of the network of the five largest regional centers.

The aim of the paper is to present the economic potential of Hungarian cities based on the specific definition of roles. In this analysis, the economic performance and structure and changes in the economy of the five largest regional centers and their catchment areas are organized in a unified structure. The diversity of the cities is the most interesting feature of the study, as there are no two similar settlements, and these special features make the Hungarian city network special. Urban development is influenced by the qualities acquired in the past. The changes in the economic and social system, which were more frequent and more complex in our region compared to the Western European countries, and the processes of market transformation sometimes brought the whole country under enormous pressure leading to the reorganization of territorial processes. The different ages left their marks on the cities, and this research also aims to identify the most prominent ones. In the case of the largest regional centers, we seek to investigate the dominant characters that can promote the development of the settlement network of their environment and support their role and tasks within their own environment. The aim of the research is to analyze the position of the five largest regional centers in the Hungarian spatial structure, since we believe that their position in the Hungarian settlement hierarchy does not determine, but rather influences their development. The aim is to examine what kind of tasks the domestic regional centers can fulfill and whether they can fulfill their expected role. Another goal is to explore the functions through which they can provide resources to their environment.

\section{THEORETICAL BACKGROUND}

Most theoretical concepts identify economic potential with employment potential and firm productivity (Beluszky \& Győri, 1999, 2003; Rechnitzer, Csizmadia \& Grosz, 2004; Rechnitzer, Páthy, \& Berkes, 2014; KSH, 2014). In this research the interpretation was formulated in a similar way, but not entirely following this idea. Economic activity is mainly emphasized in those centers which have a strong presence of economic institutions and a geographical concentration of enterprises, including large-scale Fordist mass production 
plants. An important basis of the research is the study of Molnár et al. (2018): the character of Hungarian big cities shows marked differences in the specific economic performance indicators and the structural characteristics. For the most part, the processing industry is dominant; Györ shows an outstanding performance, the economic performance of Pécs, Szeged and Debrecen related to public services is strong. The present study also includes this approach by including the settlements of the catchment area.

As a result of its strong economic potential, the catchment area will also be the dominant economic server for the center; suppliers, partners, service providers may appear in neighboring settlements. It not only concentrates economic potential but also radiates to its area. Economic potential is examined through two dimensions. On the one hand, the structure of the economy is a defining characteristic. This refers to the existence and quantity of economic institutions, the characteristics and demographics of the composition of enterprises. On the other hand, economic efficiency is the other aspect of the interpretive framework. Efficiency is usually defined as the materials received from economic activity, the sum value of production. In addition to the center, we also seek to examine the economic efficiency and structure of the settlements in the catchment area, because the changes of the last decades have also had an impact on catchment areas. By change or process we mean the consequences due to the transformation of the market economy in the nineties, the effect of which is most visible in the economy - through this, of course, in employment as well.

The basic assumption is that the economic performance and structure can be clearly determined on a theoretical and methodological level. However, it must be seen that it is very difficult to determine what economic potential means and assign it an indicator through which we can make relevant statements about the economy of a city. It is necessary to examine how balanced the role of cities and catchment areas in the economy is (typical or atypical processes), how it has changed, whether the economic performance and structure of catchment area settlements is actually visible or not considered significant.

An area that is connected to the city due to one or even several of its functions, triggering the physical movement of the population of the surrounding area due to the use of urban goods, is called a catchment area. One of the tools for this is the institutional system, with the help of which the center can mediate its functions to the population of the surrounding area, as well as the economic agglomeration, which creates an employment catchment area. Commercial and service units and functions can also form an area around the center. In line with the "central location" theory, it can be stated as a basic law that people living in the immediate, short-range environment of the center show intense and close attachment to the 
center (agglomeration zone), but the distance is related to the degree of attraction, which may appear on the horizon of the population (attraction, by which the area of the temporary attraction zone may be formed).

There are several known methods for delimiting the catchment area, two of which are highlighted. One group is made up of gravity models based on spatial distance and mass. The theory states that the more central functions a center performs, the more extensive its area of attraction will be and the more its area will be able to attract mass (Reilly 1929 quotes Nagy G. 1996; Kiss \& Szalkai, 2014). The testing of the gravity model was also received with interest by Beluszky (1967), who was mostly concerned with the experimental application of large-area attractiveness. Other Hungarian researchers were also interested in the model and its application possibilities (Nagy G. 1996; Süli-Zakar, 1996, Kiss \& Bajmócy, 2001), and even the methodology of the topic inspired researchers (Sikos, 1984; Nemes Nagy \& Piros 1984; Dusek, 2003). The gravity model was of great interest in the late 1990s and after the turn of the millennium, but there were several methodological errors in its application (see the response of Dusek (2011) to the discussion paper by Nagy (2011) on the possibilities of using the gravity model to delimit urban areas). We accept and agree that the application of the gravity model is problematic, inducing a number of methodological questions (rather than answering them).

Another method is empirical delimitation. Beluszky (1981) was the most emblematic researcher to use this method; delimiting the catchment area of the cities based on the frequency of visits to the center (e.g. commuting to work and school, health, customer traffic, etc.). This method is also widespread in Hungarian research, with the help of which the catchment area of some Hungarian cities was examined, for example, Eger (Bodor \& Pénzes, 2012), Nyíregyháza (Beluszky, 1974), Szolnok (Nagy R. 1988), Gyöngyös (Bujdosó, 2009), Szekszárd (Fodor \& Hajdú, 1985), Debrecen (Papp, 1981), Győr (Hardi, 2014), and Tiszafüred (Vadász, 1981). Most of these are called complex delimitations, involving several sectors (e.g. health, education, trade, employment), and the different sectoral catchment areas (layers) have been formed into one complex. The aim of this study is not to delimit a complex catchment area, only to highlight the economic-employment space.

There are special sector catchment areas that are delineated according to a certain aspect; such as transport (Szalkai, 2010; Tóth \& Nagy, 2013), trade (Györi 2010), commuting (Szabó P. 1998, Hardi 2005, 2014), education (Hardi 2007; Kuttor \& Péter, 2016), economy (Kozma, 1998; Koppány, Kovács, \& Szabó, 2014), labor market (Sütő, 2008; Pénzes, Molnár \& Pálóczi, 2014), and Pálóczi et al. (2016) examined the functional regions in Hungary based on 
commuting data (with a complex method). Among these researches, the following should be highlighted. Hardi's (2014) independent, calculated catchment area is similarly based on the proportion of commuters. VÁTI (Salamin, Radvánszky, \& Nagy, 2008) carried out a delimitation of the labor market catchment area similar to the present research in connection with the RePUS project (Benini \& Naldi 2007), the aim of which was mainly to analyze the characteristics of the settlement network. However, the labor catchment areas organized around the centers were also presented.

Important and relevant results for the present research are adopted from the study of Koós (2007) who deals with issues of economic suburbanization (and its relation to employment) and identifies economic suburbanisation areas in Hungary, which forms the theoretical basis of the study. He found that in addition to the center, agglomerations also show a significant economic performance (based on 2004 data), which the study attempts to verify, also presenting the subsequent processes. The results support the creation of clusters based on firm density. It depicts a static state and does not show the change, the direction of examination is also different; the goal is to identify the centers.

Based on the latter detailed studies and agreeing with the findings of Pálóczi et al. "The most regular and massive personal relationship between the employment centers and the surrounding settlements is commuting to work" (Pénzes, Molnár, \& Pálóczi, 2014: 475), it became justified to create an independent, calculated, commuting-based catchment method.

\section{OBJECTIVES AND METHODS}

\section{Territorial delimitation}

As a first step, territorial delimitation is required. As a priority, the center should not be regarded as a self-standing unit, excluding its surroundings and territorial connections, so we decided to designate a catchment area. The basis for this is the attraction of labor. The most important research antecedent of the delimitation is the delimitation of HCSO agglomerations and settlement complexes in 2014, which has already been discussed before, but here we present the basic differences between the present research and one carried out by the $\mathrm{HCSO}^{1}$.

\footnotetext{
${ }^{1}$ The HCSO has prepared a delimitation of labour market districts, which, although not closely related to the study, is important to mention. The atlas was developed according to the method of Coombes and Bond (based on the number of employees), the full version of the study indicates commuters above 5\% in each labour market district, but the districts themselves are based only on the optimal and minimum number and proportion of employees and not commuters (HCSO, Regional Atlas - Other territorial delimitations, 2014).
} 
The latter is based on 10 indicators and imposes four conditions on municipalities;

1) the complex index prepared using the 10 indicators should be higher than the rural average;

2) the condition according to which settlements located within 25 minutes can be entered has been deleted;

3) no emigration should occur;

4) (boundary condition; emphasis on the role of indicator 10) a min. of $10 \%$ of the resident population or min. $30 \%$ of locally employed employees commute to the center (HCSO 2014, Tóth G. 2014). ${ }^{2}$

The study provides a good basis, but our research topic justifies its rethinking, as the methodology had to be adapted to the diversity of economic potential. As our hypothesis suggests; each role may have a different spatial extent, and the purpose of measuring change over time requires the same, so it is necessary to expand the narrower agglomeration framework and examine it within a larger catchment area.

Table 1 Differences between agglomeration and catchment area

\begin{tabular}{|c|c|}
\hline Agglomeration & Catchment area \\
\hline $\begin{array}{l}\text { - a certain number of cities and populations } \\
\text { - economic, infrastructural (not only geographical) } \\
\text { concentration } \\
\text { - based on urbanization processes } \\
\text { - self-organizing and organic } \\
\text { - consists of an integrated settlement body, } \\
\text { characterized by territorial concentration } \\
\text { - there are also horizontal (and multi-directional) } \\
\text { connections between the settlements } \\
\text { - a well-functioning form of a functional urban area } \\
\text { - characterized by a growing population (the whole } \\
\text { area) } \\
\text { - housing construction activity characterizes the } \\
\text { settlements surrounding the center } \\
\text { - the majority of jobs for the active population are } \\
\text { located in the center } \\
\text { - measurement: with several dynamic and static } \\
\text { indicators, conditions, constraints }\end{array}$ & $\begin{array}{l}\text { - can be connected to the control panel } \\
\text { due to one or more functions } \\
\text { - physical movement between the } \\
\text { center and the surrounding } \\
\text { settlements can be monitored (can be } \\
\text { delimited along this) } \\
\text { - instrument: institutional system and } \\
\text { economy } \\
\text { - larger in the agglomeration due to re- } \\
\text { drawing } \\
\text { - measurement: by gravity model } \\
\text { (Dusek } 2003, \text { Nagy G. 2011) or by } \\
\text { experience }\end{array}$ \\
\hline
\end{tabular}

Source: Own compilation

\footnotetext{
${ }^{2}$ A similar study was conducted by Faluvégi (2008: 1094) with the following constraints: urban center: 5000 and more locally employed. Rural center: 1200-4999 employed locally. Urban center ring or co-center: daily commuters $>40.0 \%$.
} 
It further reinforces the finding that a catchment area should be designated: almost none of the characteristics of the agglomeration are relevant to the demarcated areas. In particular, for example, the criterion of a growing population: since 2010, in 305 of the 480 settlements, the migration difference is negative, in 45 settlements it is over 15 per thousand; and a boom in housing construction: 196 settlements did not build new housing between 2011 and 2016 .

In this research, we did not use the complex index (delimitation by the census in 2011 is applied as basis for a longitudinal analysis) presented above; as this is an area of attraction, we only measured the role of the center's attraction by modifying the fourth criterion, which is a boundary condition. As commuting is a good representation of key employment actors and thus connects the settlements in the area with the center, we use particular delimitation formulae and approaches (for which previous research has provided a good basis and some issues are similar to them). We assigned tolerances to two types of indicators: one is the proportion of commuters to the center within the commuters, and the other is the proportion of commuters to the center within the total number of employees. It can be seen that the two types do not always coincide, so we used a combined approach to delineate the catchment area. We set a threshold of 10\% for employees and 30\% for commuters; if the settlement meets one of the conditions, it is included in the catchment area we use (i.e. examined separately along two conditions). The largest catchment areas that can be established are not always territorially continuous (this is especially evident in the case of Miskolc). In the case of commuters, the daily domestic commuters are the basis (2011 census data), the population data indicated in the tables is the resident population at the beginning of 2017. In the case of the different solutions, the indicated population data do not include the data of the "correctional" - ensuring territorial continuity - settlements. Comparing the delimitation of particular and HCSO, the size of each agglomeration / catchment area is as follows (Table 2):

Table 2 Comparison of the results of the CSO and this particular delimitation

\begin{tabular}{|l|c|c|c|}
\hline & Present research & HCSO & HCSO category \\
\hline Debrecen & 34 & 13 & metropolitan settlement complex $^{3}$ \\
\hline Györ & 106 & 68 & agglomeration \\
\hline Miskolc & 112 & 36 & agglomeration \\
\hline Pécs & 163 & 41 & agglomeration \\
\hline Szeged & 28 & 15 & metropolitan settlement complex \\
\hline
\end{tabular}

Source: Own compilation

\footnotetext{
${ }^{3}$ according to its definition (HCSO 2014): there are strong functional relations between the center and the settlements in its (narrow) surroundings, as a result of intensive land use, urban living conditions can be observed in the settlements surrounding the center. In our case, we assume the strength of functional relationships, however, the rest of the definition does not - or only partially - characterizes the catchment areas we delimit.
} 
Berkes, J.

\section{Selection of basic data}

The basic data were selected along the two dimensions (efficiency, structure). In particular, the indicators by which both economic structure and efficiency can be expressed should be listed.

The structure can be examined with simple business demographics and efficiency with multiple income indicators. The first and most important aspect of the selection is that in the case of small settlements as well - more or less - relevant, interpretable data should be included in a complex indicator that is also suitable for measuring the economic dimensions of the center. This is already a difficult but important point in the analysis.

\section{Examination of data quality}

The aforementioned objectives and strict data quality criteria significantly limit the range of data that can be used. We could have listed several other income indicators among the performance indicators, but on the one hand they were mostly not interpretable in the case of smaller settlements (e.g. export sales), or the data showed multicollinearity (e.g. per capita PIT base). Similar constraints (e.g. the number of large companies in the case of small settlements) narrowed down the possibilities when designing the structural data group. Based on the results of the tests examining the combined effect of the variables, the relevance of the dimensions can be determined. The data below show the criteria in the two dimensions (the measurement covered 480 settlements, including centers).

Table 3 Data measuring economic potential

\begin{tabular}{|c|c|c|}
\hline Data & Unit & Source \\
\hline \multicolumn{3}{|l|}{ Economic structure (KMO 0,547; Bartlett's Sig. 0,000): } \\
\hline total number of enterprises per 100 inhabitants & pc / inhabitant & T-STAR \\
\hline $\begin{array}{l}\text { the proportion of non-agricultural companies of all collective } \\
\text { entrepreneurship }\end{array}$ & $\%$ & T-STAR \\
\hline the proportion of total income from the business & $\%$ & NAV TA \\
\hline \multicolumn{3}{|l|}{ Economic efficiency (KMO 0,540; Bartlett's Sig. 0,000): } \\
\hline gross value added per employee & HUF/person & NAV TA \\
\hline value of fixed assets per employee & HUF/person & NAV TA \\
\hline inland income per taxpayer & HUF/person & NAV TA \\
\hline
\end{tabular}

Source: Own compilation 
Table 4 Bivariate correlation coefficients

\begin{tabular}{|l|c|c|c|}
\hline Economic structure & $\begin{array}{c}\text { total number of } \\
\text { enterprises per } 100 \\
\text { inhabitants }\end{array}$ & $\begin{array}{c}\text { the proportion of non- } \\
\text { agricultural companies } \\
\text { of all collective } \\
\text { entrepreneurship }\end{array}$ & $\begin{array}{c}\text { the proportion of total } \\
\text { income from the } \\
\text { business }\end{array}$ \\
\hline $\begin{array}{l}\text { the proportion of non- } \\
\text { agricultural companies of all } \\
\text { collective entrepreneurship }\end{array}$ & 0,279 & 0,135 & \\
\hline $\begin{array}{l}\text { the proportion of total income } \\
\text { from the business }\end{array}$ & 0,442 & & \\
\hline
\end{tabular}

\begin{tabular}{|l|c|c|c|}
\hline Economic efficiency & $\begin{array}{c}\text { gross value added per } \\
\text { employee }\end{array}$ & $\begin{array}{c}\text { value of fixed assets per } \\
\text { employee }\end{array}$ & $\begin{array}{c}\text { inland income per } \\
\text { taxpayer }\end{array}$ \\
\hline $\begin{array}{l}\text { value of fixed assets per } \\
\text { employee }\end{array}$ & 0,592 & & \\
\hline inland income per taxpayer & 0,312 & 0,167 & \\
\hline
\end{tabular}

Source: Own compilation

\section{Making the basic variables suitable for comparison and for indexing}

It is important that the basic data are made comparable in all cases, specified according to their definition. We have been examining changes in economic performance and structure since the 1990s, so we collect and transform all basic data for the following years: 1992, $1995,2000,2005,2010,2015 / 2016$. Because it is important for change to be perceptible, it is necessary to establish five-year intervals.

After the selection and transformation of the basic variables, the characteristics of the 480 settlements (the five centers and the settlements in the catchment area) are examined; paying particular attention to outliers, which significantly influence the mean values of our sample, thus defining the economic "role" we formulate, so outliers should be excluded for all variables.

\section{Weighting and aggregation}

We also use empirical weights for economic structure and performance. In the case of both dimensions, the weight obtained in the formation of a factor gives the weight values of the variables, which are applied uniformly for each year. In this case, we adjust to the weights of the main component of performance and structure for the last year (2015), we keep it throughout the analysis phase as follows: 
Table 5 Communality and factor weights of data measuring economic potential

\begin{tabular}{|l|c|c|}
\hline Data & $\begin{array}{c}\text { Communalit } \\
\text { y }\end{array}$ & $\begin{array}{c}\text { Factor } \\
\text { weights }\end{array}$ \\
\hline total number of enterprises per 100 inhabitants & 0,697 & 0,835 \\
\hline the proportion of non-agricultural companies of all collective entrepreneurship & 0,323 & 0,568 \\
\hline the proportion of total income from the business & 0,571 & 0,755 \\
\hline gross value added per employee & 0,773 & 0,873 \\
\hline value of fixed assets per employee & 0,672 & 0,813 \\
\hline inland income per taxpayer & 0,302 & 0,553 \\
\hline
\end{tabular}

Source: Own compilation

Factor analysis is no longer involved. Keeping in mind the accuracy and interpretability of the analyzes, we form the complex indicator for each settlement with a different method, and by normalizing the indicators, we believe that we can obtain much more accurate results.

The aggregation was done in the following six steps:

1. Normalization (range)

2. Weighting

3. Add weighted values along the dimensions

4. Normalization of dimensions

5. Addition of normalized values $=$ complex indicator

6. Comparison $($ center $=100 \%)$

\section{RESULTS}

The results of the complex indicator are shown in the maps. The results - along with the analysis - do not seek to comply with national trends, only with themselves. The results are only suitable for comparing the five largest regional centers and their catchment areas. The economic resources of the largest regional centers and their regions are presented individually. The results show how different the development paths of the five centers are. The latest (available) base maps as well as the road network layer were used for the study, therefore this should be taken into account when analyzing according to the conditions of previous years. 
Figure 1 Results of the economic complex indicator for 1992 and $2015^{4}, \%$ (The center is Györ $=100 \%)$

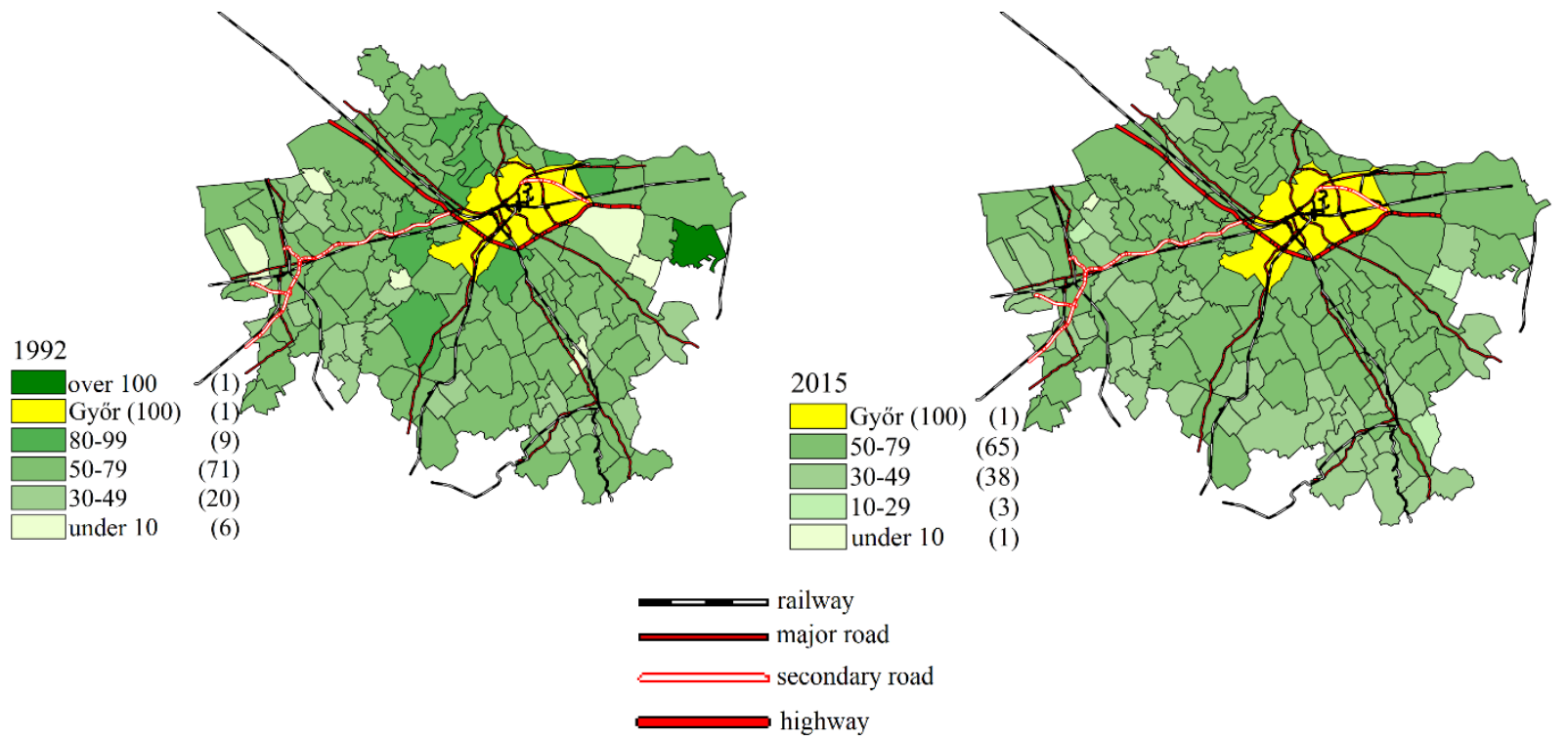

Source: Own compilation

The figure shows that in the case of the catchment area of Györ, the economic efficiency of the center in the years before the turn of the Millennium was exceeded by two settlements (eg Enese in 1995), so we could talk about the presence of sub-centers. In 1992, Enese, where two major employers settled at that time (actually in 1996, but replaced a company already operating there, replacing its economic potential) and in Bábolna, the operation of IKR highlighted the cities (this is a huge company engaged in agricultural activities: fertilizer, pesticide, seed, crop trade), which was maintained up to 1995. After 2000, the dominance of the settlements in the catchment area - which until then had an economically prominent role ceased, the economic power of the region became concentrated in Györ, in the center, thus homogenizing and bringing the settlements of the district to an equal level. Thus, the consequences of the nineties and the market transition clearly strengthened the central economic role of Györ, concentrating significant resources. Of course, this is also distorted by the appearance at the center of a huge employment company, Audi Hungaria Zrt., the world leader in engine production. Obviously, with the inclusion of outlier data, the economic efficiency of smaller centers seems to be weaker, but we must not forget that the catchment area of Győr still has the most dominant economic potential compared to the other four regions. The appearance of a large company of a similar size significantly influences the role of the center, seemingly pushing the economy of the catchment area behind it, however, despite appearances, the "serving" settlements (e.g. Enese also employs hundreds of people in

${ }^{4}$ Due to space limitations, maps for all years are not included in the study 
the automotive industry) can build on and benefit from the centre's economy. The reverse is also true, as the center has a limited capacity to accommodate new economic actors, and these will appear in the industrial areas of other settlements due to the differentiation of the reasons for deployment. The industrial infrastructure of the district is also prominent, which also serves the processes described above excellently.

Figure 2 Results of the economic complex indicator for 1992 and $2015^{5}, \%$ (The center is Pécs $=100 \%)$
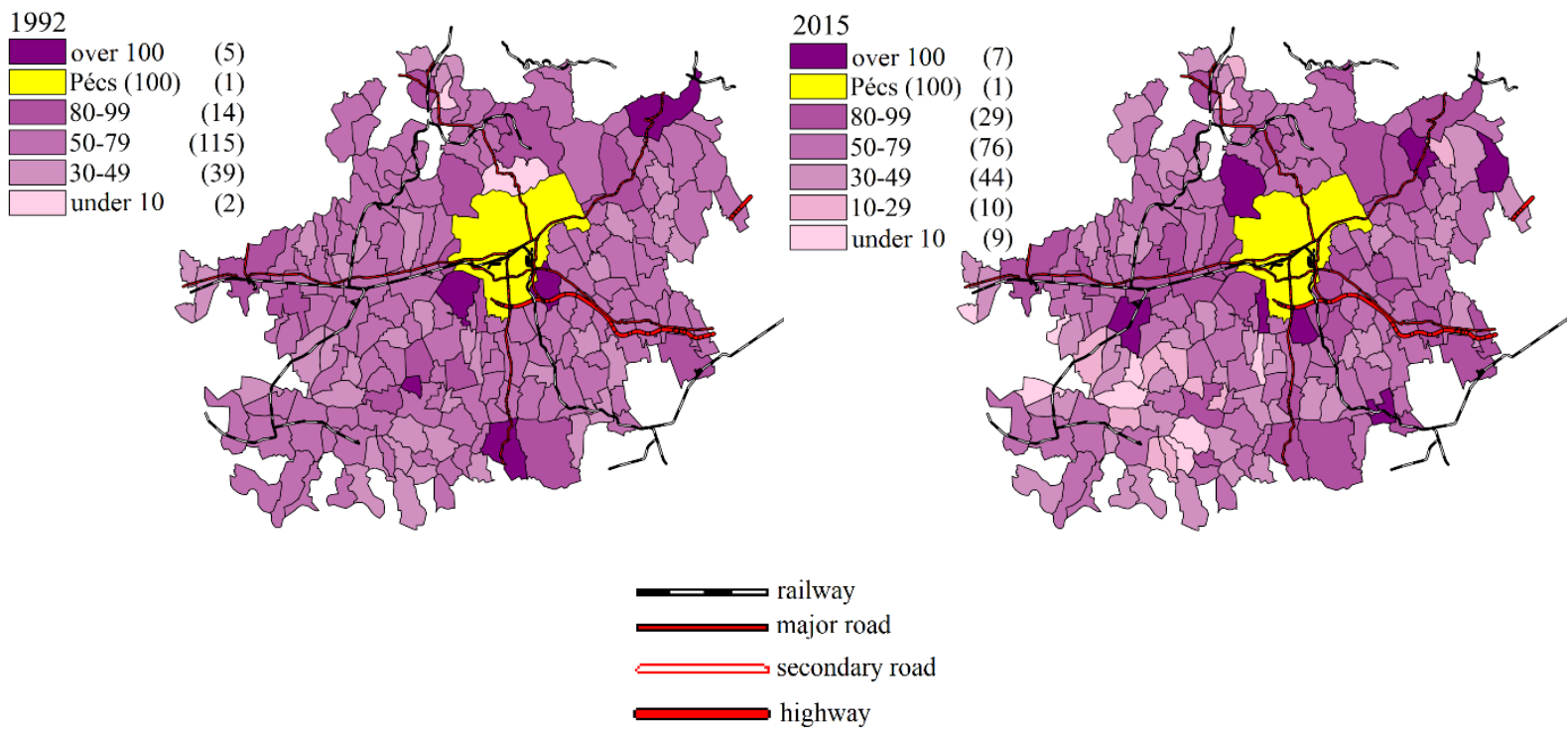

Source: Own compilation

The area of Pécs shows a much more segmented picture. There have been and still are settlements with strong economic potential since the early 1990s. In 1992 Mecseknádasd, Pellérd, Kozármisleny, Harkány stood out, in 1995 the area was dominated by roughly similar economic potential, there was no outstanding settlement. In 2000, however, Pécsudvard and Keszü were characterized by a stronger economy than the center. In 2005 Harkány and Pogány led the ranking, by 2010 the circle was expanded with Keszü, Palkonya and Kisdér. In 2015, Orfü, Zengővárkony, Feked and Királyegyháza produced similarly outstanding economic indicators. How can this be explained? The Mecsek $^{6}$ mountain, the Harkány bath and the Villány wine region all generate revenues that support the economy. It is also obvious that the economic indicators of Pécs and its region lag far behind those of Györ or Miskolc, for example, in this analysis this is not clear because we compared the settlements to the center. No large employer settled here, which would have attracted its partners and suppliers

${ }^{5}$ Due to space limitations, maps for all years are not included in the study.

${ }^{6} \mathrm{It}$ is situated in the Baranya region, in the north of the city of Pécs. 
to the surrounding settlements and industrial parks, thus having a significant impact on education and infrastructure investments. Although the economy of the region is not performing well, it is important to see the stagnation. After Pécs, the second largest settlement is Komló, which was famous for its prosperous coal mining as a socialist industrial city since the 1950s, but the analysis shows that its economy has lagged far behind its center in recent years and it failed to recover in the declining period following its golden age. Thus, the Pécs region already shows a more heterogeneous economic picture than Györ. It is clear that the relative decline of the peripheries compared to 1992 is more spectacular, with a markedly narrower effect on the center.

Figure 3 Results of the economic complex indicator for 1992 and 20157, \% (The center is Szeged $=100 \%$ )

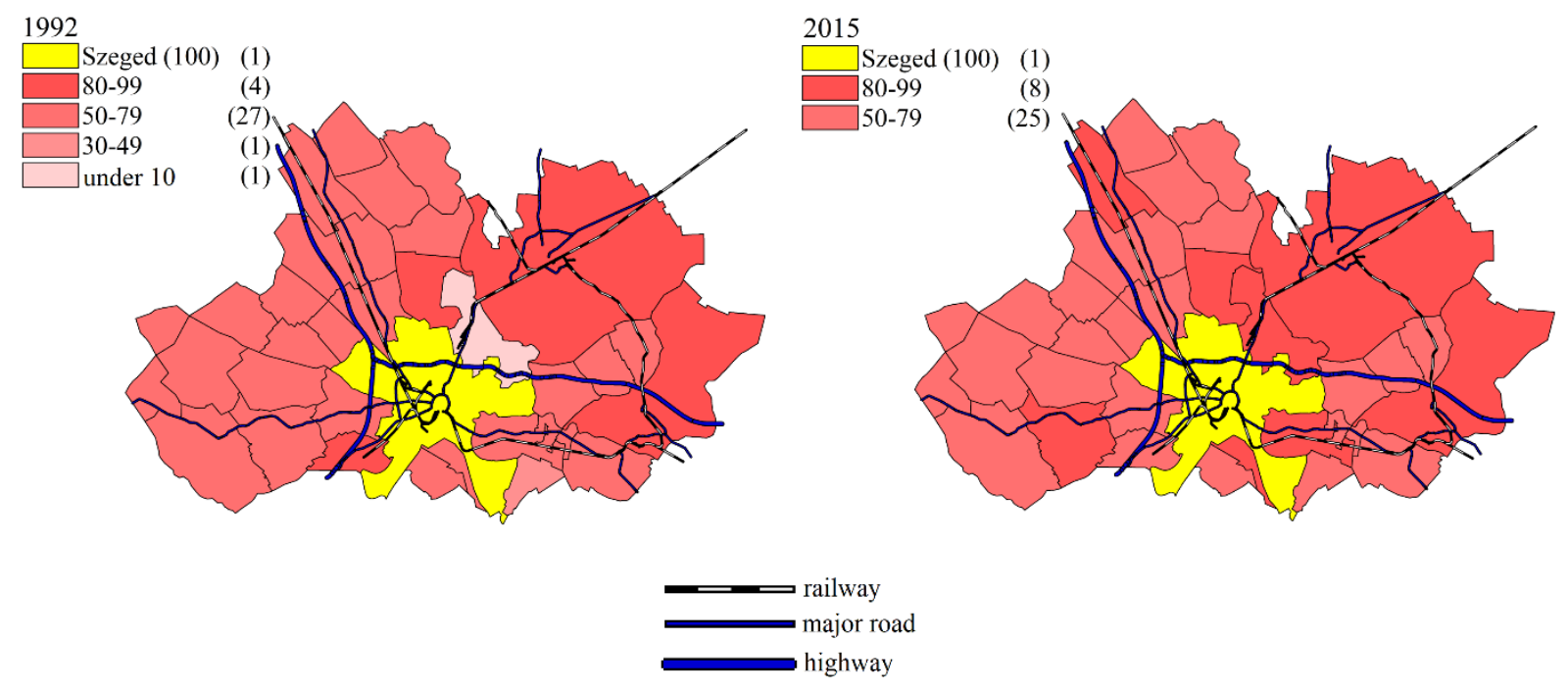

Source: Own compilation

Szeged, as a center, has the strongest economic function since the beginning of the nineties, but smaller centers also appear faintly (e.g. maps edited on the basis of data from 1992, 1995, 2005, 2010 show a similar picture). In 2000, Zsombó and Röszke recolored the map with a performance of over $100 \%$. All these settlements shine in the central light of Szeged, enjoying its proximity. In the middle of the nineties, around the turn of the Millennium, the number of emigrants increased dramatically in Zsombó, where small and medium-sized enterprises engaged in food industry, agriculture and agricultural activities also appeared. Röszke also stands out from the "crowd" as the Röszke border crossing, called the country's southern gateway, has a significant impact on the economy, with a higher

${ }^{7}$ Due to space limitations, maps for all years are not included in the study. 
proportion of businesses involved in trade and services. Agriculture and the related significant food processing industry cannot be neglected, as the factory units of two large well-known factories operate in the settlement: Unilever Kft., and the manufacturer of KNORR products. After that, we have not seen a striking leap in the last decade, the center of Szeged has maintained its role of concentrating the strongest economic resources ever since. The economic and territorial structure of the region is similar to that of Györ, with the largest occupants settling in the center. The catchment area is also less fragmented geographically, it is surrounded by settlements with a larger area than Pécs or Miskolc. The more even development of the region is also influenced by the fact that the confluence of the Maros and the Tisza divides its region.

Figure 4 Results of the economic complex indicator for 1992 and $2015^{8}, \%$ (The center is Debrecen $=100 \%$ )

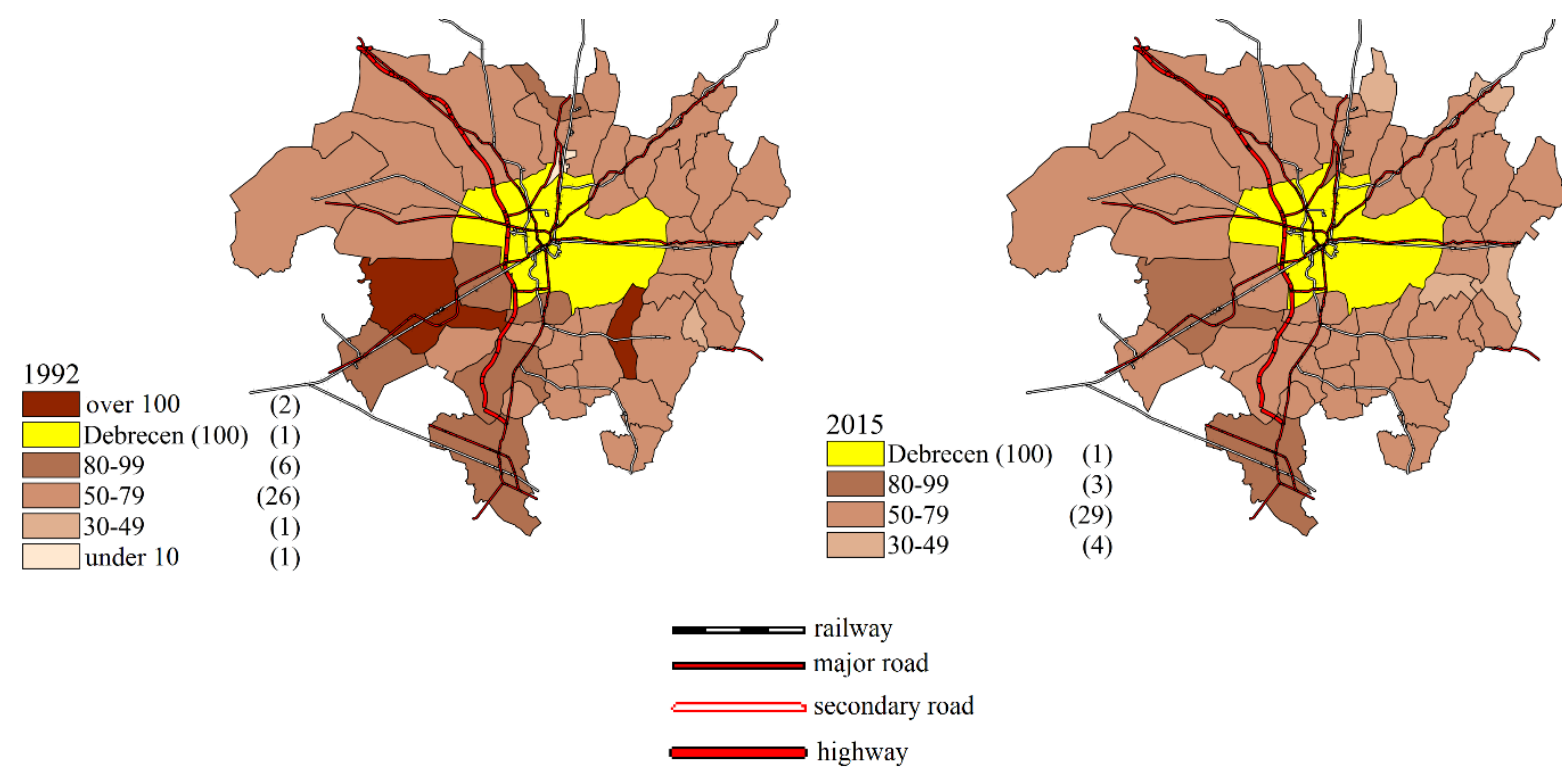

Source: Own compilation

In the case of Debrecen - and likewise in Györ - a kind of homogenization can observed. From the beginning of the nineties to the turn of the Millennium, the dominant economic subcentral role is seen in Monostorpályi (before the change of regime the largest employer in the settlement was the agricultural cooperative), Hajdúszoboszló and Kaba (in the latter case, the Sugar Factory and later Evonik, which pays a business tax of 90 million, representing 30\% of all business tax, and closed its plant in Kaba in April 2018). In the case of Hajdúszoboszló, the exploitation of thermal resources meant an increase, but the significant investment made in the center in recent decades "pushed back" the economic potential of the settlements in the

${ }^{8}$ Due to space limitations, maps for all years are not included in the study. 
region. Such was the establishment of the four companies with the highest sales revenues: Chemical Seed arrived in the '90s, E.ON has been operating since '91, the famous pharmaceutical company has been a member of the TEVA group since '95, and FAG has been operating since '99. Many suppliers were attracted to the industrial areas of Debrecen. The economic power of Debrecen, due to the prominent role of the IT sector or electronics industry (Kozma G., Molnár E. 2018), is the second among the five cities, and it also plays a convincing role in this field among the cities with county status. Although it is lagging behind Györ, it is engaged in stable strong economic activity, which is also evidenced by the investments of the last two decades. It intends to strengthen its strong chemical and pharmaceutical center, as well as its economic areas in other directions, as 23 investments have been made since 2014, thus flowing 200 billion forints of working capital into the region, creating 4,700 new jobs. The central role of Debrecen is likely to follow the trends of the past and will continue to strengthen (since the construction of the BMW site in Debrecen is currently underway).

Figure 5 Results of the economic complex indicator for 1992 and $2015^{9}, \%$ (The center is Miskolc $=100 \%$ )

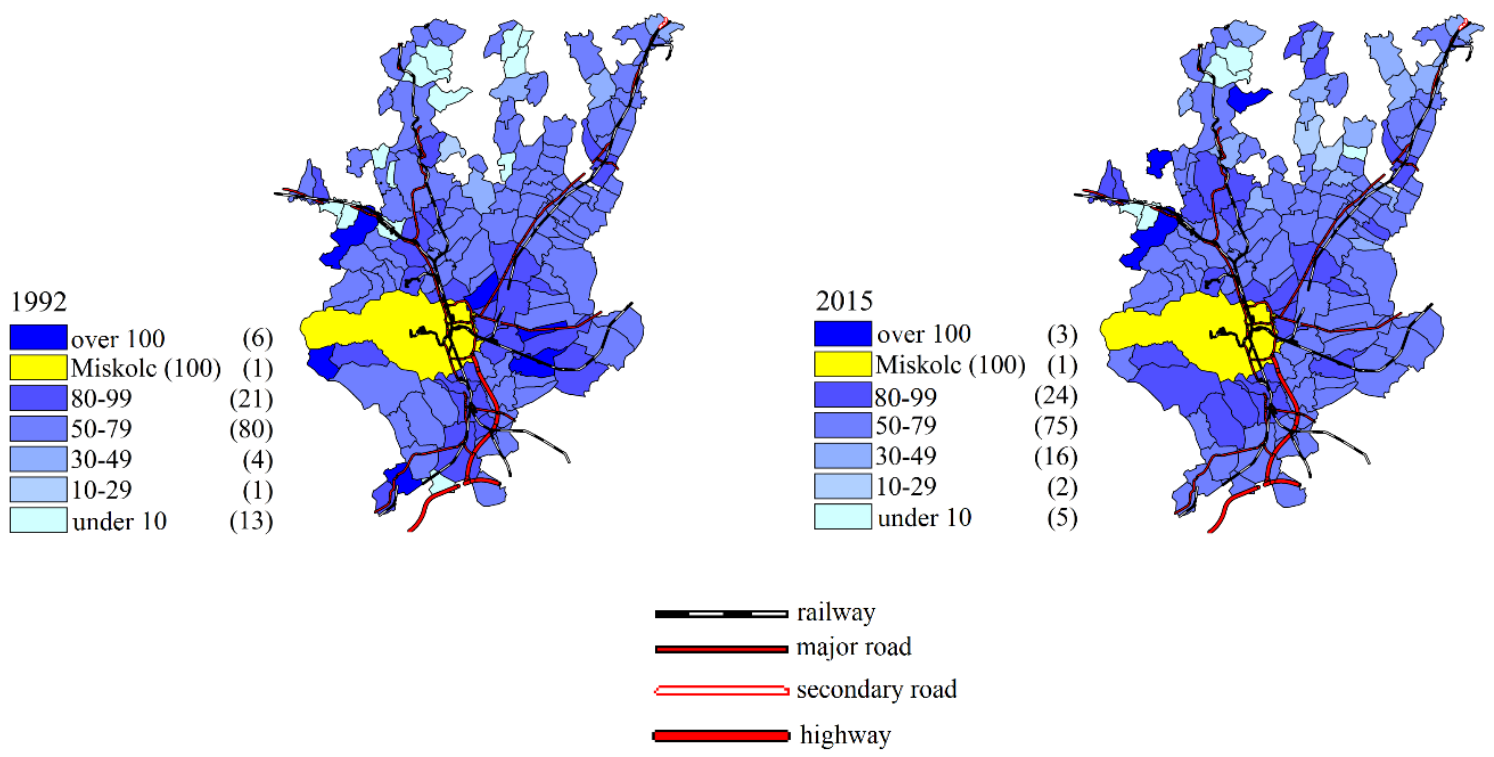

Source: Own compilation

The center of Miskolc, like Pécs and Győr, is also surrounded by smaller, fragmented settlements, thus coloring the catchment area. In the early 1990s, the settlements around the center gained a stronger economic role, and then they faded over time. Only two settlements can be highlighted, which have a stable high economic potential in each year examined:

${ }^{9}$ Due to space limitations, maps for all years are not included in the study 
Berkes, J.

Kazincbarcika and Böcs. In the case of the latter village, the dominant company is the Borsodi Brewery, which has been operating in the settlement since 1973. Kazincbarcika, the other famous socialist industrial city, is the "Hungarian chemical citadel", home to BorsodChem's $100 \%$ foreign-owned company and employing more than two and a half thousand people, with annual net sales in excess of HUF 500 billion. This is a huge revenue for the city, so it continues to play the role of economic sub-center in the region. Sajóbábony was able to preserve the economic potential of the center from the nineties to the turn of the Millennium presumably because one of the largest employing chemical companies operating in the settlement (SVIP Kft. - a non-profit Ltd. that maintains the local industrial park (TEVA Pharmaceutical Industry operates a unit there) was able to overcome the difficulties associated with the change of regime. In 1992, the Mátra Power Plant showed greater but unstable economic activity due to the Bükkábrány coal mine. In 2015, Kazincbarcika and Bőcs will also play a dominant economic role, although Felsőnyárád, Galvács, Szemere (2005), Varbó (2000), Répáshuta (1992) will appear next to them, behind which we cannot find a real process ("small settlement effect"). In the case of Miskolc, the strongest proof was obtained from the assumption that, although it is possible, it is not worthwhile to examine the center without its area. The strongest "sub-center" can be found here, Kazincbarcika, which showed an average score of one and a half times the main economic component compared to Miskolc. Kazincbarcika and Miskolc are important for their coexistence and co-operation - both in terms of labor flow, employment and increasing urban revenues - and it can be clearly shown that they influence each other's economic development.

\section{Changes in economic potential}

The study can also be extended to measure the change in potential, which helps to identify the narrow agglomeration that is prospering economically around the five largest Hungarian regional centers.

We based this on a simple absolute difference. The value of the starting time of the calculated complex score was subtracted from the data of the last available year. Compared to the catchment area calculations presented above, these illustrations aim to show how the settlements in the catchment areas have performed relative to themselves (not the center). Based on this, the following results were obtained. 
Figure 6 Changes in the economic performance and structure of the catchment area of Györ ${ }^{10}$

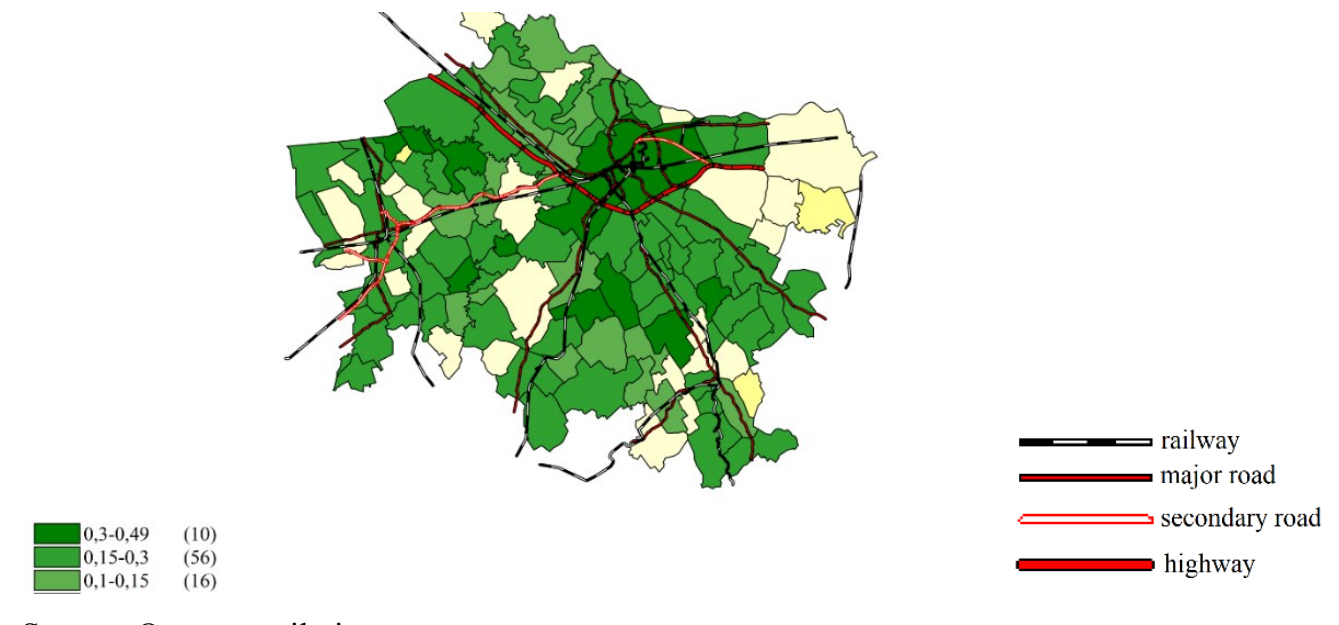

Source: Own compilation

The relatively wide agglomeration of Györ has moved in a positive direction in recent decades in economic terms. Smaller islands (Dunaszeg, Rábapatona, Tét) moved in a slightly positive direction (they improved by a maximum of 0.1 tenth on their complex index despite an overall decline). Basically, the whole region is characterized by a positive shift, only three settlements are characterized by economic decline (Cakóháza, Sikátor and Bábolna; the latter has a stronger role, the other two were characterized by a modest economic upturn in the early 1990s but they are basically small settlements). The expanding economic agglomeration of Györ can obviously be explained by the rapid development of the center. The emergence of Audi Hungaria Zrt. gave this an initial impetus, which further attracted other investments to the region, for which the presence of the appropriate industrial infrastructure provided essential funds. Of course, there have been other major investments that are not related to the emergence of the German automotive multinational, and the investments are significantly influenced by the favourable geographical location of the region.

The economic power of Pécs has clearly shown a decrease or a negligible increase in recent decades, which justifies the strange territorial division in terms of its economic role. In some places it is an island-like settlement, and the Bóly-Mohács area is producing a positive leap, which is presumably due to the appearance of a larger investment compared to the size of the settlement. The center shows signs of stagnation, while the small settlements in its immediate vicinity fragment the area. The southwestern part of the catchment area, a part of Ormánság region, is showing a drastic decline. The emergence of point-like economic growth

\footnotetext{
${ }^{10}$ Based on the absolute difference between the 2015 and 1992 complex indicators.
} 
has already been demonstrated above; there was no settlement with permanent strong economic potential at any of the time points examined, as evidenced by the figure above.

Figure 7 Changes in the performance and structure of the catchment area of Pécs ${ }^{11}$

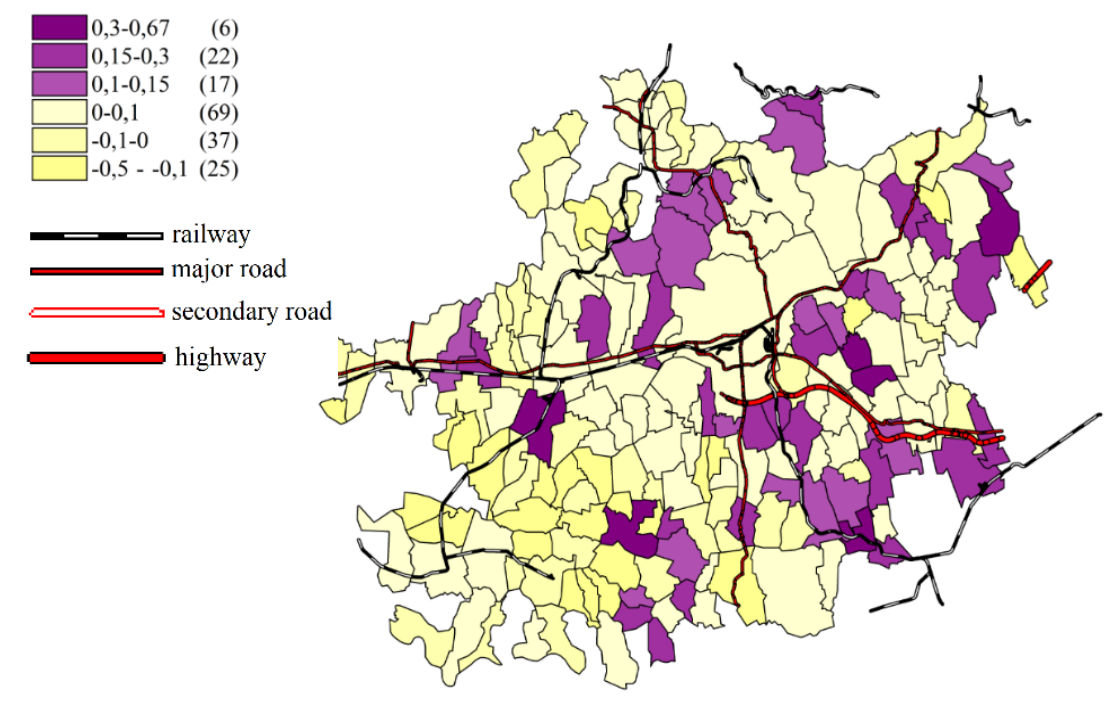

Source: Own compilation

Figure 8 Changes in the economic performance and structure of the catchment area of Szeged $^{12}$

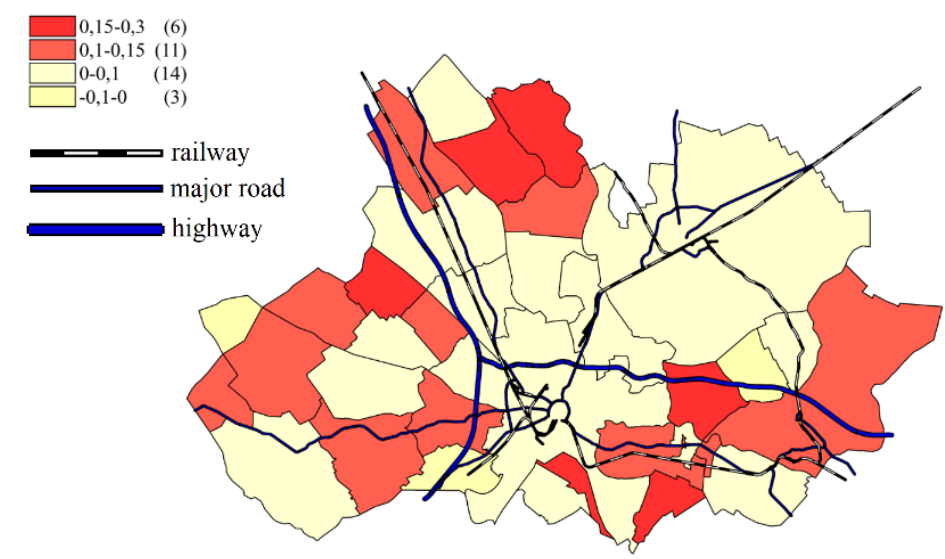

Source: Own compilation

The catchment area of Szeged is more difficult to analyze due to the specificity of the settlement network. Slightly improving or stagnant economic potential characterizes the region, only three settlements show a negative shift (Pusztamérges, Röszke, Óföldeák). Szeged is stagnant, while Makó has improved its situation. This is somewhat contradictory to the previous findings, as we measured the economic performance of the settlements to the

\footnotetext{
${ }^{11}$ based on the absolute difference between the 2015 and 1980 complex indicators.

${ }^{12}$ based on the absolute difference between the 2015 and 1980 complex indicators.
} 
center there, which clearly has reinforced the dominance of Szeged in recent decades. The area with a single economic driving force is divided into three parts after the absolute measurement of change. The border of these three parts is the highway, the Tisza and the Maros. It is important to emphasize that this is not a deteriorating economic performance, but a „stagnant on solid feet” or strengthening potential, so we characterize it as a stable operation.

Figure 9 Changes in the economic performance and structure of the catchment area of Debrecen $^{13}$

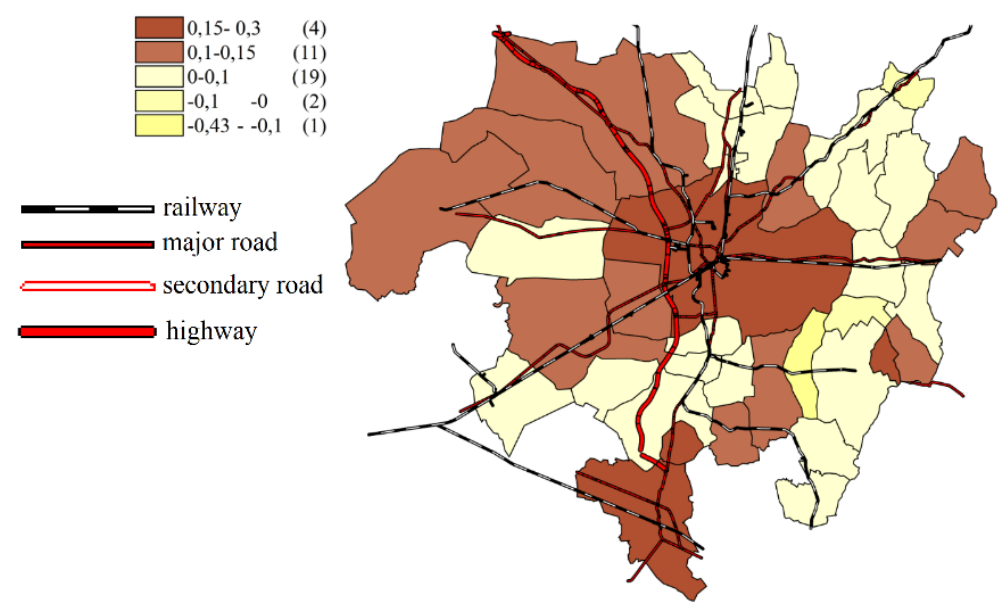

Source: Own compilation

The economic catchment area of Debrecen is concentrated in the west, but not in a contiguous area. Some small settlements in the east (eg Kokad, Nyírábrány, Álmosd) do not show real economic efficiency. Only one settlement plunged deep in terms of economic efficiency and structure; Monostorpályi (-0.43). The other two (Újléta, Nyírmihálydi) also declined slightly, but basically the other stagnated. In addition to Debrecen, Berettyóújfalu also produced economic growth.

The economic structure and performance of the Miskolc catchment area are also fragmented. Compared to themselves, only those settlements that are located along the main road were able to move in a positive direction. Clearly, the center is the concentrator, which gravitates the other settlements in a star shape. Here, the lag is significant too $(-0.51$, but only in one settlement), but only four settlements belong to this category (unlike Pécs, where it is 25).

\footnotetext{
${ }^{13}$ based on the absolute difference between the 2015 and 1980 complex indicators.
} 
Figure 10 Changes in the economic performance and structure of the catchment area of Miskolc $^{14}$

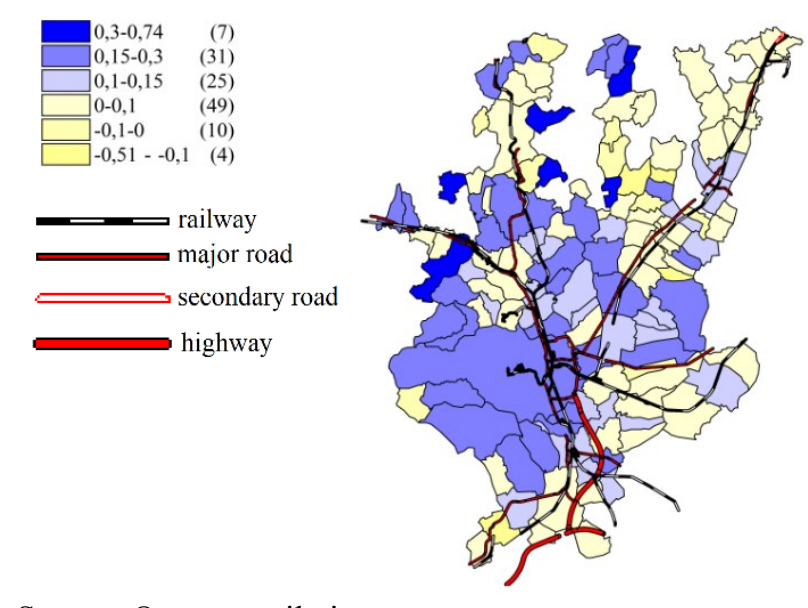

Source: Own compilation

\section{DISCUSSION}

It is impossible to define the role of centers without the surrounding network of settlements. The control panel can only appear as a leader in a space if it has an environment that is an integral part of it and performs the most important tasks at the top of the division of labor. Empirical research was conducted on how this position changed with regard to economic potential. The study has showed that the change in the function of centers influences the catchment area, which can be multi-directional;

- the role of the catchment area will increase as the center rises (Györ),

- with the weakening of the center, the power conditions of the catchment area change, smaller - but basically weak - centers can evolve (Pécs),

- besides the stagnant processes of the center, the atony of the catchment area is also felt, but a steadily strong center also "breathes" the area, from which the traditional center also benefits (Miskolc).

- in sharp contrast to that, besides a solid central role strong sub-centers are also active, thus stabilizing the developing region as well as the center (Szeged),

- the center is stable and balanced, but it is unable to energize the entire catchment area (Debrecen).

\footnotetext{
${ }^{14}$ based on the absolute difference between the 2015 and 1980 complex indicators.
} 
Trends in development are different for the catchment areas of the five largest regional centers. We have verified that the districts are centralized in terms of functionality, and we have partly proved that these are due to different reasons:

- There is a coherent catchment area around Győr, which is mainly due to its stable economic structure and the ability to adapt to changes.

- Pécs can be considered a weak center concerning the three functions, which causes disintegration of the catchment area. The reason for this is primarily the failure of the monocultural economy (and the lack of adaptation to it), which resulted in a significant loss of labor force attractiveness and consequently in a deterioration of the employment structure.

- Szeged is a strong center, but the structure of its catchment area is rearranged into two sub-centers that have been stabilized over time (processes relating to the history of market towns).

- The catchment area of Debrecen is divided into an undeveloped eastern periphery and a developing western part, which can be explained by inadequate infrastructure and urban historical processes.

- The settlements of the catchment area of Miskolc show the highest standard deviation from the point of view of development; it has a strong sub-center, but the most declining settlements are in the catchment area of this regional center. The reason for this - similarly to Pécs - is the poor ability to adapt to change.

In each case a common process can be observed, a return effect between the center and its area.

\section{CONCLUSION}

In the case of the five largest regional centers, three directions can be identified; on the one hand Györ's outstanding performance in all functions, on the other hand the decline of Miskolc and, at the same time, its "career search", and Debrecen, Szeged and Pécs which reflect similar traits in many cases. At this stage of the study, the main - but cautious finding is that the regional "central" status can be questioned in the case of these cities. It can be clearly shown that Györ concentrates a significant share of functions, but the same cannot be stated in the case of the other four cities, and indeed they tend to be closer to the average of towns with county rights (the question is which city cluster approached the other). 
The need to examine the catchment area is indisputable, and two main conclusions can be drawn. On the one hand, the unquestionable performance of Györ homogenises the area and there is no other center in the agglomeration, but in the case of Szeged and Debrecen it is less clear, while the economic respirator of the catchment area of Miskolc is Kazincbarcika, and Pécs is spectacularly fragmented (not because of the presence of small centers but rather because it is a weak center). In Hungary no research has been conducted spanning such a long time period on the largest regional centers and their catchment areas that would allow to compare them with themselves and each other (using a complex methodology). The utility of the results of the research is high, as they can support decision-making processes of both city government and regional development actors.

\section{REFERENCES}

Beluszky, P. (1967). A magyar városok központi szerepköre. Statisztikai Szemle, 6, 543-563. Beluszky, P. (1974). Nyíregyháza vonzáskörzete. (Földrajzi Tanulmányok, 13). Budapest: Akadémiai Kiadó.

Beluszky, P. (1981). A városi vonzáskörzetek (városkörnyékiség) vizsgálatának elvi módszertani kérdései. Budapest: ÁSZI.

Beluszky, P. (2014). Budapest - zászlóshajó vagy vízfej? Gödöllő: Szent István Egyetemi Kiadó.

Beluszky, P., \& Győri R. (1999). Magyarországi városhálózat és az EU-csatlakozás.Tér és Társadalom, 1-2, 1-30.

Beluszky, P., \& Győri, R. (2003). A város a láz, a nyugtalanság, a munka és a fejlődés. Magyarország városhálózata a 20. század elején. Korall, 11-12, 199-238.

Benini, R., \& Naldi, P. (2007). Strategy for a Regional Polycentric Urban System in CentralEastern Europe Economic Integrating Zone. RePUS Final Report. RePUS, s.l.

Bodor N., \& Pénzes, J. (2012). Eger komplex vonzáskörzetének dinamikai vizsgálata. Tér és Társadalom, 3, 30-47.

Bujdosó, Z. (2009). Gyöngyös város vonzáskörzetének változása az elmúlt negyedszázadban. Földrajzi Közlemények, 1, 59-74.

Dusek, T. (2003). A gravitációs modell és a gravitációs törvény összehasonlítása. Tér és Társadalom, 1, 41-58.

Dusek, T. (2011). Inadekvát adatok és egyéb módszertani kérdések a gravitációs modell alkalmazása során. Területi Statisztika, 6, 674-677.

Egyed, I. (2016). From uniformity towards unequality in regional development policy: the case of France. Deturope, 3, 32-51.

Faluvégi, A. (2008). A foglalkoztatás területi-települési szerkezete Magyarországon. Statisztikai Szemle, 12, 1077-1102.

Fodor, I., \& Hajdú, Z. (Eds.) (1985). Szekszárd vonzáskörzetének vizsgálata. Szekszárd: Tolna Megyei Tanács, Pécs: MTA RKK Dunántúli Tudományos Intézete.

Győri, R. (2010). A Kisalföld kereskedelmi vonzáskörzet-rendszere 1925-ben. Tér és Társadalom, 2-3, 303-309.

Hajdú, Z., Horeczki, R., \& Rácz, Sz. (2017). Changing settlement networks in Central and Eastern Europe with special regard to urban networks. In Lux, G., \& Horváth, Gy. 
(Eds.), The Routledge Handbook to Regional Development in Central and Eastern Europe (pp. 123-140).

Hardi, T. (2005). Határon átnyúló ingázás, munkavállalás az osztrák-magyar határtérségben. Tér és Társadalom, 2, 65-81.

Hardi, T. (2007). A Széchenyi István Egyetem vonzáskörzete. In Lados, M., \& Rechnitzer, J. (Eds.), Egyetem a régióért (pp. 93-112). Pécs-Győr: MTA Regionális Kutatások Központja.

Hardi, T. (2014). Az ingázás térbeli jellegzetességeinek változása az Észak-Dunántúlon, különös tekintettel Győr munkaügyi vonzáskörzetére. In Lados, M. (Ed.): $A$ gazdaságszerkezet és vonzáskörzet alakulása (pp. 49-69). „A györi jármüipari körzet, mint a térségi fejlesztés új iránya és eszköze" c. kutatás monográfiái 5. Győr: Universtitas-Győr Nonprofit Kft.

Kiss, J., \& Bajmócy, P. (2001). Városi funkciójú központok és elméleti vonzáskörzeteik az Alföldön. Tér és Társadalom, 1, pp. 65-89.

Kiss, J. P., \& Szalkai, G. (2014). A foglalkoztatás területi koncentrációjának változásai Magyarországon a népszámlálások ingázási adatai alapján, 1990-2011. Területi Statisztika, 5, 415-447.

Koppány, K., Kovács, N., \& Szabó D. R. (2014). Város és vonzáskörzete: gazdasági kapcsolatrendszer és növekedés Vázlat a győri jármüipari körzet regionális makromodelljének kidolgozásához. Tér és Társadalom, 2, 1-31.

Kovács, Z. (2017). Városok és urbanizációs kihívások Magyarországon. Magyar Tudomány, 3, 302-310.

Kozma, G. (1998). A gazdasági élet szereplőinek térbeli preferenciái. Falu-Város-Régió, 5, 7 14.

Kozman, G., \& Molnárn, E. (2018). The role of industrial parks in the economic development of Debrecen. Tér Gazdaság Ember, 4, 35-49.

HCSO (2014). Magyarország településhálózata I. Agglomerációk, településegyüttesek. Budapest: Központi Statisztikai Hivatal.

HCSO (2014). Regional Atlas - Other territorial delimitations. In http://www.ksh.hu/regionalatlas_other_territorial_delimitations (Downloaded: 2020.09.30.)

Koós, B. (2007). A szuburbanizációs folyamat a magyar gazdaságban. Közgazdasági Szemle, 4, 334-349.

Kuttor, D., \& Péter, Zs. (2016). Changing Position and Catchment Area of the University of Miskolc, Faculty of Economics. Deturope, 3, 124-137.

Molnár, E., Dézsi, Gy., Lengyel, I. M., \& Kozma, G. (2018). Vidéki nagyvárosaink gazdaságának összehasonlító elemzése. Területi Statisztika, 6, 610-637.

Nagy, G. (1996). A gravitációs modell alkalmazási lehetőségei a településen belüli mozgások tanulmányozására. Tér és Társadalom, 2-3, 149-156.

Nagy, G. (2011). A gravitációs modell felhasználásának lehetőségei a várostérségek lehatárolásában. Területi Statisztika, 6, 656-673.

Nagy, R. (1988). Szolnok város vonzásviszonyai (1949-1980). Alföldi Tanulmányok, 12, 219-236.

Nemes Nagy, J., \& Piros, Gy. (1984). Térbeli népesség- és anyagáramlások vizsgálata gravitációs modellel. Matematikai és statisztikai módszerek alkalmazási lehetöségei a területi kutatásokban. (Földrajzi Tanulmányok, 19). Budapest: Akadémiai Kiadó.

Papp, A. (1981). Debrecen vonzáskörzete. Alföldi Tanulmányok, 5, 177-204.

Pénzes, J., Molnár, E., \& Pálóczi, G. (2014). Helyi munkaerő-piaci vonzáskörzetek az ezredforduló utáni Magyarországon. Területi Statisztika, 5, 474-490. 
Pálóczi, G., Pénzes, J., Hurbánek, P., Halás, M., \& Klapka P. (2016). Attempts to delineate functional regions in Hungary based on commuting data. Regional Statistics, 1, 23-41.

Rácz, Sz. (2019). Development Processes of Regional Centres in Central and Southeast Europe - From State Socialism to Dependent Market Economies. Deturope, 2, 92-100.

Rechnitzer, J., Páthy, Á., \& Berkes, J. (2014). A magyar városhálózat stabilitása és változása. Tér és Társadalom, 2, 105-127.

Rechnitzer, J., Csizmadia, Z., \& Grosz, A. (2004). A magyar városhálózat tudásalapú megújító képessége az ezredfordulón. Tér és Társadalom, 2, 117-156.

Reilly, W. J. (1929). Methods for the Study of Retail Relationships. University of Texas Bulletin, No. 2944.

Salamin, G., Radvánszki, Á., Nagy, A. (2008). A magyar településhálózat helyzete: értékelés. Falu Város Régió, 3, 6-26.

Sikos, T. T. (Ed.) (1984). Matematikai és statisztikai módszerek alkalmazási lehetöségei a területi kutatásban (Földrajzi Tanulmányok 19). Budapest: Akadémiai Kiadó.

Süli-Zakar, I. (1996). A régió: földrajzi integráció. In Süli-Zakar, I. (Ed.), A terület- és településfejlesztés alapjai (pp. 139-159). Budapest-Pécs: Dialóg Campus.

Sütő, A. (2008). Város és vidéke rendszerek és típusaik Magyarországon. Falu-Város-Régió, $3,51-64$.

Szabó, P. (1998). A napi ingázás kérdésköre a kilencvenes években Magyarországon. Tér és társadalom, 4, 69-89.

Szalkai, G. (2010). Várostérségek lehatárolása a közúti forgalom nagysága alapján a magyar határok mentén. Tér és Társadalom, 4, 161-184.

Tóth, G., \& Nagy, Z. (2013). Eltérő vagy azonos fejlődési pályák? A hazai nagyvárások és térségek összehasonlító vizsgálata. Területi Statisztika, 6, 593-612.

Tóth, G. (2014). Az agglomerációk, településegyüttesek lehatárolásának eredményei. Területi Statisztika, 3, 289-299.

Vadász, I. (1981). Tiszafüred vonzáskörzete (Studia Geographica, 4). Debrecen: KLTE Földrajzi Intézet. 